\title{
Education System in Malaysia and Indonesia for Human Resource Development
}

\author{
Ikhsan Othman \\ Faculty of Education and Human Development, Sultan Idris Education University \\ 35900 Tanjong Malim, Perak, Malaysia.
}

\begin{abstract}
Malaysia and Indonesia are implementing their own education system in developing their human resources for nation development. This paper discusses the systems in the countries limited to the main framework of education namely the philosophy of education; curriculum and its implementation; and assessment of students learning. From the philosophy of education point of view, divinity is the underlying aspect of education in Malaysia as well as in Indonesia, with students as the subject of education. Students of today are future human capital for the nation. Therefore education is necessary to develop students' natural potential to produce individuals who are intellectually, spiritually, emotionally and physically balanced and harmonious in line with the purpose of the human existence as inheritors of the earth. From the curriculum point of view, both countries are implementing a standard curriculum which is integrated and dynamic parallel with current needs and global challenges. The content of the curriculum includes knowledges, skills and values with innovations from time to time dynamically. From the aspect of students' learning, the quality of process and the quality of learning outcomes are based on competencies. The assessment of learning does not just focus to final examination results but also ensures the quality of students' learning process. Generally, it is undeniable that there are some similarities between the two countries in developing their human resources through education. On a positive note, the similarities should be viewed in terms of the benefit to both countries. As the global challenges keep on changing, one day it might become ideas to have mutual collaborations between the two countries in generating higher quality of human resources through education.
\end{abstract}

Keywords: Education system, human resource development

\section{Introduction}

Malaysia and Indonesia are two countries that are in the same cluster called the Malay Archipelago or Nusantara. Thus the people of the two countries are said to be allied in a group of Malay stock. Both countries were once colonized by western colonial powers, namely Portuguese, Dutch, English and also occupied by Japanese form the East during the Second World War. After gaining independence from colonialization, Malaysia and Indonesia rose to construct the country by exploiting their natural resources as well as their human resources. Basically there is a strong relationship between education and human resources development. Misalignment in the treatment done in education will result to the generation of low quality human resources. Thus, Donna Dare (1996) in his article emphasisizes that 'education is a human resources development'. Almost countries spent larger budget for education in the countries for a better result of more effective and efficient workers for the work place of tomorrow.

Although Malaysia and Indonesia are in the same cluster called the Malay Archipelago or Nusantara, the two countries are independent countries. Therefore, they implement their own educational system for the purpose of developing human resources for their countries. The term human resources is used interchangably with the term human capital. However, the term human capital or in Malaysian language modal insan is often used in Malaysia. On the other hand, the term human resources or in Indonesian language sumber daya manusia is often used in Indonesia. It is believed that students of today are future human capital for nation development of the countries. Therefore, the effort put in education is obviously 
significant in generating world quality of human resources or workers with higher skills who are demanded by most employers.

\section{Education In Malaysia And Indonesia}

There are similarities between education system in Malaysia and Indonesia. Both countries also aimed to develop quality human resources through their education system. This paper discusses the systems in the countries limited to the main framework of education namely the philosophy of education; curriculum and its implementation; and assessment of students learning. On a positive note, the similarities should be viewed in terms of the benefit to both countries in building up their human resources for the sake of their nation development. A part from that, it might also be an initial idea of mutual collaboration between the two countries regarding with the matter.

\section{Philosophy of Education}

Education in Malaysia is based on a specified philosophy of education. The philosophy was in the implicit form until 1988 when the philosophy was expressed explicitly. The philosophy is then enshrined in Malaysia Education Act 1996 as the National Education Philosophy (NEP) which states as follow.

"Education in Malaysia is an ongoing effort towards further developing the potential of individuals in a holistic and integrated manner, so as to produce individuals who are intellectually, spiritually, emotionally and physically balanced and harmonious, based on a firm belief in devotion to God. Such an effort is designed to produce Malaysian citizens who are knowledgeable and competent, who possess high moral standards, and who are responsible and capable of achieving high level of personal well-being as well as being able to contribute to the harmony and betterment of the family, the society and the nation at large"

Malaysia Ministry of Education (2006).

It is obviously stated in the NEP that education in Malaysia is an on-going effort based on a firm belief in devotion to God. Such effort is to further develop the natural human potential so as to produce individuals who are intellectually, spiritually, emotionally and physically balanced and harmonious. A well balanced and harmonious individuals are peoples who posses integrated personality and able to enjoy contentment and happiness spiritually. At the same time the individuals will also possess skills and competencies; feel grateful and ready to face challenges and competitions; as well as possessing capability to solve problems. The individuals will further have ability to achieve higher level of personal well-being as well as being able to contribute to the harmony and betterment of their family, society and the nation. In addition, the aspect of divinity is the underlying aspect of the education in Malaysia with students as the subject of education. The philosophy of education in Malaysia has clear intention to be achieved.

For Indonesia, education in the country is based on Pancasila. Pancasila is the national ideology of Indonesia. As stated in the 1945 Constitution of Indonesia, Pancasila consists of five basic principles that are inter-related and cannot be separated from each other in the aspects of divinity, humanity, society and statehood. The principles are as follows.

Belief in the one and only God.

Just and civilized humanity.

The unity of Indonesian.

Democracy guided by the inner wisdom in the unanimity arising out of deliberations amongst representatives.

Social justice for all the people of Indonesia.

Basically it can be said that Pancasila is the philosophy of education in Indonesia. Pancasila as the basis for the implementation of the education system in Indonesia confirmed in MPR Decree No. 11/MPR/1988. This is also confirmed in UUSPN No.2 of 1989, that national education in Indonesia is Pancasila. Based on Pancasila, education is essential to develop abilities and characters of Indonesian. Education is also aimed to develop students' potential in order to be individuals who are faithful to God; individuals who are noble in their character, physically fit, knowledgeable and competent, 
creative, independent; and individuals who will become citizens of Indonesia with democratic and accountable to the people and the country. This corresponds to Article 3 of Law No. 20 of 2003 as folows.

"The National Education functions to develop the capability, character, and civilization of the nation for enhancing its intellectual capacity, and is aimed at developing learners' potentials so that they become persons imbued with human values who are faithful and pious to one and only God; who possess morals and noble character; who are healthy, knowledgeable, competent, creative, independent; and as citizens, are democratic and responsible."

Table 1 summarizes the similarities of education between Malaysia and Indonesia from the philosophy of education points of view.

Table 1: Similarities of Education Between Malaysia and Indonesia

\begin{tabular}{|l|l|l|}
\hline Aspects of Education & Malaysia & Indonesia \\
\hline Principles & Based on a firm belief in God. & Faith and devotion to God Almighty. \\
\hline Goals & $\begin{array}{l}\text { Human beings with strength in intrinsic and } \\
\text { instrumental dimension anchored to the divine. }\end{array}$ & $\begin{array}{l}\text { Human beings who are faithful to God, even- } \\
\text { tempered and dignified civilization. }\end{array}$ \\
\hline Element & $\begin{array}{l}\text { Basic and natural human potential that is the } \\
\text { potential of intellect, spirit, emotion and physical. }\end{array}$ & $\begin{array}{l}\text { Human potential involves cognitive, affective } \\
\text { and psychomotor. }\end{array}$ \\
\hline Process & $\begin{array}{l}\text { Education takes place on an ongoing basis based } \\
\text { on the National Education Philosophy. }\end{array}$ & Education takes place based on Pancasila. \\
\hline Outcomes & $\begin{array}{l}\text { Human capital with well-being and capable of } \\
\text { contributing to the betterment of the family, society } \\
\text { and country. }\end{array}$ & $\begin{array}{l}\text { Citizens of a democratic and responsible and } \\
\text { character to become human resources to the } \\
\text { country. }\end{array}$ \\
\hline
\end{tabular}

Based on the above discussion about the philosophy of education in Malaysia and Indonesia; it can be generalized that the aspect of divinity is the underlying aspect of education in Malaysia as well as in Indonesia with students are the subjects of education. Students as the subjects of education need to be developed their potential naturally in a balanced and harmonious way. In addition, the focus of education in the two countries generally is to awaken students to become human beings with characters, that is those who are able to achieve high level of personal well-being as well as being able to contribute to the harmony and betterment of their family, society and the nation. This is reiterated by Suyanto (2015), where the human character is refering to the way of thinking and behaving of an individual to live and work together in the family, community, nation and state. In addition, the peoples of good character are those who are capable to make decisions and take responsibility for the decision made. This is important for the generation of quality human capital who can survive in on-going global competitions and in the world of technologies that continues to advance so rapidly.

\section{Curriculum and its Implementation}

The implementation curriculum in Malaysia and Indonesia is based on the philosophy of education that has been set as the bottom line. Curriculum and its implementation should not drift off (derailed) from its runway that is its philosophy. The development of intrinsic dimension and instrumental dimension of the students is in line with the faith and piety that is based on trust and obedience to God. Indonesia is also implementing the concept of an integrated curriculum with no separation or compartmentalization between the domains of cognitive, affective and psychomotor. The concept of integration in the curriculum includes the integration of knowledges, values, skills and divinity. The concept of integration in the curriculum also involves aspects of theory and practice as well as contextual between flog and real lives. Thus aspects of local knowledges are also taken into account in the curriculum in Malaysia as well as in Indonesia.

In Malaysia education system, the curriculum has been progressing since after its independence until now. After the independence, Malaysia implemented curriculum with general syllabus known as Primary School Curriculum (KLSR being 
its acronym in Malay) for primary schools; and Secondary School Curriculum (KLSM being its acronym in Malay) for secondary schools. The primary school curriculum was then changed to Primary School New Curriculum (KBSR being its acronym in Malay) in 1982 and as Primary School Integrated Curriculum (also KBSR being its acronym in Malay) in 1988. The secondary school curriculum changed to Secondary School Integrated Curriculum (KBSM being its acronym in Malay) in 1988.

Currently Malaysia is implementing standards curriculum starting from 2011 known as Primary School Standard Curriculum (KSSR being its acronym in Malay). It was in accordance with Circular No. 11/2010 Ministry of Education dated October 14, 2010. The curriculum has been implemented in stages begining with Year 1 primary schools and will be fully implemented in the primary schools up to Year 6 by 2016. The standard curriculum is also going to be fully implemented in the Malaysia secondary schools known as Secondary School Standard Curriculum (KSSM being its acronym in Malay). The implementation of the standard curriculum in Malaysia is an upgrading of the integrated curriculum that was previously implemented. Thus the concept of the integrated curriculum is still present in the standard curriculum. The content and learning standards that are outlined in the standard curriculum are specifically aimed towards ensuring students to acquire knowledges, skills and values and to achieved basic competencies that are needed in the current and future demand.

In Indonesia, the national curriculum in its education system is also experiencing its growth from initially been developed in 1947; that was after the independence of the country. It was then followed by series of changes that happened in 1952 , 1964, 1968, 1975, 1984, 1994, 2004, 2006 and 2013. The changes of the curriculum in 2013 were for the tenth times and the national curriculum was called Curriculum 2013. The national curriculum in Indonesia is basically contextual in its nature and in accordance with pupils' learning environments. Other than cognitive domain, Curriculum 2013 emphasizes the attitude of honesty and decency that is under affective domain and skills such as practical tasks or school projects that are under the psychomotor domain. There is always integration between the cognitive domain, affective domain and psychomotor domain in the implementation of Curriculum 2013. However Curriculum 2013 in Indonesia has been implemented only for a semester before it was held for further revision and improvement based on a Circular No. 423.5/154/Sj distributed to schools. The former curriculum that is Kurikulum Tingkat Satuan Pendidikan 2006 was again implemented in the second semester of 2014/2015 school session to replace Curriculum 2013.

From the above discussion, conclusions can be drawn that Malaysia and Indonesia have similarities in terms of curriculum change or curriculum inovation in their education system in line with the concept of dynamic curriculum to meet the current as well as the future needs and challenges. Both countries are also implementing standard and integrated curriculum in their education syatem. Malaysia and Indonesia from time to time upgrade the curriculum in their education system to uplift their peoples and societies to higher level of skills, competencies and self-esteem to become quality human resources who posess the capabilites in competing global economic challenges in the post-modern world.

From the administrative point of view, curriculum in Malaysia is administred with top-down concept with the Ministry of Education act the as the top body, especially with regard to policy and legislation; assisted by the State Education Department and District Education Office in connection with the execution. The top-down concept in curriculum administration is also practiced in Indonesia. Educational administration at the provincial and district level in Indoneia is done to carry out the administration and management at the national level. Related aspects of local based curriculum (Kearifan Lokal) for example, is much depend on each and every province in the country. Thus the administration and management at the provincial level is as complimentary to what is implemented at the national level. Table 2 is a summary of the similarities between Malaysia and Indonesia in terms of curriculum and its implementation in their respective education system.

Table 2: Similarities Between Malaysia and Indonesia in Curriculum and its Implementation

\begin{tabular}{|l|l|l|}
\hline Aspects & Malaysia & Indonesia \\
\hline \multirow{3}{*}{ Progress } & $\begin{array}{l}\text { - Dynamic and continues to experience growth over } \\
\text { time. } \\
\text { - Current is the Standard Curriculum 2011. }\end{array}$ & $\begin{array}{l}\text { - Dynamic and continues to experience } \\
\text { growth over time. } \\
\text { - Latest is 2013 curriculum. }\end{array}$ \\
\hline
\end{tabular}




\begin{tabular}{|l|l|l|}
\hline Underlying Aspect & National Education Policies in education system. & $\begin{array}{l}\text { Based on the philosophy of Pancasila for } \\
\text { education across the country. }\end{array}$ \\
\hline $\begin{array}{l}\text { Administration and } \\
\text { Management }\end{array}$ & Top-down, centralized and decentralized. & Top-down, centralized and decentralized. \\
\hline Content of curriculum & $\begin{array}{l}\text { - Knowledge, values and skills (cognitive, affective } \\
\text { and psychomotor). } \\
\text { - Academic, technical and religious. }\end{array}$ & $\begin{array}{l}\text { - Knowledge, values and skills (cognitive, } \\
\text { affective and psychomotor) } \\
\text { - Competence in general, vocational, } \\
\text { religious and local based curriculum } \\
\text { (Kearifan Lokal). }\end{array}$ \\
\hline Integration & $\begin{array}{l}\text { - Human potential: include intellectual, spiritual, } \\
\text { emotion and physical. } \\
\text { - Aspects of knowledge, values, skills and } \\
\text { divinity. } \\
\text { - che integration of theory and practice and }\end{array}$ & $\begin{array}{l}\text { - Integration of the domain cognitive, affective } \\
\text { and psychomotor. } \\
- \text { Aspects of knowledge, values, skills and } \\
\text { divinity. } \\
- \text { The integration of theory with practice and } \\
\text { contextual. }\end{array}$ \\
\hline Continuity & $\begin{array}{l}\text { - Curriculum continuously from the preschool, } \\
\text { elementary school and secondary school. } \\
\text { - Practicing the concept life long education. }\end{array}$ & $\begin{array}{l}\text { - Curriculum implemented in a continuous } \\
\text { manner from preschool education, } \\
\text { elementary education, secondary } \\
\text { education to higher education. }\end{array}$ \\
\hline Sequence & By order of the contents sequent. & $\begin{array}{l}\text { According to the contents in an orderly } \\
\text { sequence. For example Mathematics are } \\
\text { taught in accordance with the level of } \\
\text { intellectual development of students. }\end{array}$ \\
\hline
\end{tabular}

Continuous effort in enhancing education system through curriculum innovation in Malaysia as well as in Indonesia is a good move towards generating world-class quality of human resources to meet the current and future demand. Therefore it should be kept in progress.

\section{Learning Assessment}

From the aspect of students' learning, the quality of process and the quality of the learning outcomes based on competencies is a priority in the context of education in Malaysia and Indonesia. Thus the assessment of student' learning does not just focus to final examination results but also ensures the quality of the process. There are tremendous needs for a change in the way of students' learning are assessed. Students' learning assessment need to change in order to actively engage them in their learning process; promote understanding; and also promote application of skills and knowledges that they have learnt. Therefore there is now a need to understand and to improve the dynamics of the learning processes and assessment system.

Education system in Malaysia implements the concept of school based assessment (SBA) in line with the implementation of KSSR. SBA does not only comparing a student to other students as in the concept of norm reference assessment. Conversely student achievement is measured based on a certain standard at a level appropriate to their learning process. This method is categorized under the concept of criterion reference assessment. At primary school level, students' achievement through SBA will contribute 40 percent to their final achievement in public Primary School Achievement Test (UPSR being its acronym in Malay) which is done at the end of Year 6 , while another 60 percent is from the final examination of UPSR.

In Indonesia assessment of students' learning is similar to that implemented in Malaysia where it involves formative assessment as well as summative assessment. Formative assessment is carried out at schools in and for the continuation of teaching and learning processes. The result of the assessment done by schools will be taken into account in overall 
achievement of National Examination (UN being its acronym in Indonesian Language). Assessment by schools accounted for 60 percent of the overall assessment of UN.

As in Malaysia, the assessment of students' learning in Indonesia is significantly viewed from various angles. Students' assessment results are used as a basis for teaching and learning process. Which mean that the assessment results are for the purpose of continuity in the following stages or levels of students' learning processes. The more students' learning assessment done in the process of learning is the better in order to ensure the development of students competencies happened positively in line with the aim to produce higher quality of human resources. Students should not only think that their learning is only for the sake of their final examination without really focus on their skills and competencies development that is actually the bottom line of the learning process. Clearer view about the aims and the process of students' learning assessment in education will bring to the upgrading the process of producing better quality of the future human resources.

Certification and selection for higher education learning as well as for job application are also amongst the significance of the assessment especially the result of the summative evaluation. Table 3 shows the similarities between Malaysia and Indonesia in terms of students' learning assessment.

Table 3: Students' Learning Assessment in Malaysia and Indonesia

\begin{tabular}{|c|c|c|}
\hline aspects & Malaysia & Indonesia \\
\hline Summative Assessment & $\begin{array}{l}\text { - Public Examination. For example UPSR, } \\
\text { Form } 3 \text { Assessment (PT3 being its acronym } \\
\text { in Malaysian Language), Malaysia Certifictae } \\
\text { of Education (SPM being its acronym in } \\
\text { Malaysian Language) and Malaysia High } \\
\text { School Certificate (STPM being its acronym } \\
\text { in Malaysian Language). }\end{array}$ & $\begin{array}{l}\text { - National Exam. For example EBTANAS } \\
\text { (Indonesian Language acronym) is now called the } \\
\text { National School Final Examination standard } \\
\text { (Indonesian acronym UASBN). }\end{array}$ \\
\hline Formative Assessment & School Based Assessment (SBA) & $\begin{array}{l}\text { - Assessment of school is at a ratio of } 60 \% \text { of the } \\
\text { overall assessment for National Examination }\end{array}$ \\
\hline $\begin{array}{l}\text { Significant of Learning } \\
\text { Assessment }\end{array}$ & $\begin{array}{l}\text { - Continuity of learning to the next level - } \\
\text { Certification for higher education. } \\
\text { - Certification to the field of employment. }\end{array}$ & $\begin{array}{l}\text { - Sustainability to the next level of learning. } \\
\text { - Certification for selection to higher education. } \\
\text { - Selection in job application. }\end{array}$ \\
\hline
\end{tabular}

Generally, it can be said that students' learning assessment in Malaysia as well as in Indonesia is seen in a wider perspective where it functions as student's diagnostic for guidance, development and remedial in their continous learning processes; and assessment also meant for the purposes of students' certification.

\section{Conclusion and Remarks}

Malaysia and Indonesia are committed to strategize their education system for the development of their human resources. Although Malaysia and Indonesia were once closely allied in Malay Archipelago or Nusantara, after the occupation and subsequent independence from colonialism, each country implements their own education system in line with the context of their respective countries. Although there are some aspects with their own unique feature in the matters related to education, it cannot be denied that there are also some unique feature of similarities between the two countries in developing their human resources through education. The similarities can be seen from the general framework as discussed above although there may be yet other aspects that can be examined in turn. On a positive note, the similarities between Malaysia and Indonesia in the education system may bring benefit to both countries in order to develop world quality of human resources for facing the world and the global challenges.

Because basically there are the similarities between the the two mentioned countries, it is not impossible to have ideas of opportunities for students of both countries to have their studies done at any educational institutions in Malaysia or in Indonesia mutually. The significance of the idea is that, the students can manage to have their wider view about the realities 
of the world and globalization. According to Malaysian Qualification Agency (MQA), National Examination (UN) in Indonesia is equivalent to Malaysia Higher Certificate of Education (STPM) examination in Malaysia. Therefore students who passed UN from Indonesia and fulfilled the requirements, can mutually joint any approprite Bachelor Degree Program in any higher institutions in Malaysia.

At present, there are quite numbers of student's exchange programs done in higher education institutions between the universities in Malaysia and universities in Indonesia. For example, students of Sultan Idris Education University in Perak (Malaysia) had their practical teaching in Palembang, Indonesia with the collaboration of Sriwijaya University. In addition, University Utara Malaysia in Kedah (Malaysia) had their students exchange program at Syiah Kuala University in Aceh (Indonesia). The concept of mutual student's exchange between Malaysia and Indonesia will potentially be better if it is extended to secondary school students too. For instance, Malaysia and Indonesia might one day collaboratively think and start to have their secondary school students exchange programs mutually. It might not for a start in the larger scale, instead it begins with a smaller scale. In term of facilities, Boarding Schools or schools with student's hostels as found in Malaysia might be convenient to support the implementation of this idea.

Any possibilities that will emerge in the globalization era such as in the aspects of politic, social, culture, economy and so on, require new approaches in human resources development. We cannot just be satisfied at our present status quo. Therefore, it might not impossible for Malaysia and Indonesia to think furthet about any mutual collaborations regarding with this matter. If it does happen then, it is better to start the efforts from the early stages of student's education level in accordance with Malay expression 'melentur buluh biarlah daripada rebungnya' (to bend a bamboo, let it start at the younger age) with the expectations that 'the students of today are the future generations of tomorrow' who are capable to become what is known as 'a clock builder rather than just a time teller'.

\section{References}

[1] Abu Bakar Nordin \& Ikhsan Othman (2008). Falsafah Pendidikan dan Kurikulum. Tanjong Malim: Quantum Books.

[2] Amsal Amri (2009). Studi Filsafat Pendidikan. Banda Aceh: Yayasan Pena.

[3] Donna Dare (1996). Education and Human Resouces Development: A Strategic Collaboration. Journal of Industrial Teacher Education. Number 3. Volume 33. Retrieved Mac 1, 2016 from http://scholar.lib.vt.edu/ejournals/JITE/v33n3/dare.html

[4] Ikhsan Othman (2015). Sabatical Leave Report (unpublished).

[5] Malaysia Education Act 1961. Kuala Lumpur: International Law Book Service. (1984).

[6] Malaysia Education Act 1996. Kuala Lumpur: MDC Publishers Printers. (1996).

[7] Malaysia Ministry of Education (2012). Buku Panduan Pelaksanaan Pentaksiran Berasaskan Sekolah. Putrajaya: Lembaga Peperiksaan Malaysia

[8] Malaysian Qualification Agency. Senarai Nilai Taraf Kelayakan Akademik Luar Negara Yang Setara Dengan Kelayakan Akademik di Malaysia. Retrieved Mac 2, 2015 from http://www.mqa.gov.my

[9] Ornstein, A.C. \& Hunkins, F.P. (1998). Curriculum: Foundations, principles and issues ( $3^{\text {rd }}$ ed.). Boston: Allyn \& Bacon.

[10] Penny Sleuth. Time Building not Time Telling. Retrieved Mac 1, 2015 from http://pennysleuth.com

[11] Suyanto (2015). Urgensi Pendidikan Karakter. Retrieved Mac 22, 2015 from http://www.pendidikan karakter.org.

[12] Tilaar, H.A.R. (1999). Pendidikan Kebudayaan dan Masyarakat Madani Indonesia. Bandung: PT. Remaja Rosdakarya. 